\title{
Gênero e etnia no nascente romance brasileiro
}

Úrsula.

REIS, Maria Firmina dos.

4. ed. Atualização do texto e posfácio de Eduardo de Assis Duarte.

Florianópolis: Editora Mulheres; Belo Horizonte: PUC Minas, 2004. 288 p.

Uma importante reedição acaba de ser realizada pela Editora Mulheres, de Florianópolis, em parceria com a Editora da PUC Minas. Tratase da publicação do romance Úrsula, que veio a público originalmente em São Luis do Maranhão, no ano de 1859, pela mão afrobrasileira de Maria Firmina dos Reis. A autora é considerada uma das pioneiras da ficção escrita por mulheres em nosso país, ao lado de Nísia Floresta e Ana Luísa de Azevedo e Castro. Mas o mérito da edição não se resume a isso.

O livro permaneceu fora de circulação por mais de um século e seu resgate vem contribuir para a reescrita de nossa história literária. Até porque inaugura uma perspectiva diferenciada quanto ao trato do problema da escravidão, que não se encontra na obra dos demais escritores do período romântico. A autora - mulher mestiça bastarda e criada sem a presença dos pais assume o ponto de vista do outro, tanto no que diz respeito à representação dos escravizados, quanto no inédito enfoque das relações de dominação patriarcal sob a perspectiva da mulher

A instigante novidade do texto de Maria Firmina reside na preocupação com a história e as raízes negras, bem como na referência constante à África, apesar do enredo protagonizado pelos jovens brancos Úrsula e Tancredo. O papel atribuído aos cativos na trama revelar-se-á fundamental para o desfecho. Além disso, os escravos aí representados em nenhum momento se identificam com os valores dominantes, nem reproduzem estereótipos, como do "negro de alma branca", a exemplo de Pa Tomás, Domingos, Isaura e tantos outros. submetidos à "consciência social subordinada", a que mais tarde se reportaria Clóvis Moura. Ao contrário, conservam sua etnicidade e suas práticas culturais como forma de resistência. $E$ essa atitude integra o processo de sua afirmação como sujeitos.

"A mente! Isso sim ninguém pode escravizar!", afirma o personagem de Maria Firmina. Ao contrário do que se praticava na literatura da época, o parâmetro moral existente no texto não se coaduna com os valores sociais hegemônicos: as qualidades de Túlio são derivadas da nobreza de seu sangue africano, e se tornam mesmo elemento de comparação entre o escravo e o personagem branco: "é que em seu coração [dele, Tancredo], ardiam sentimentos tão nobres e generosos como os que animavam a alma do jovem negro" (grifos nossos, p. 25).

Outro fator a ressaltar é o ponto de vista gendrado, que permite a crítica às formas de subordinação da mulher no patriarcado brasileiro, herdeiro das relações coloniais. Em uma reflexão inédita na escrita de seu tempo, Maria Firmina dos Reis fala como mulher e associa a dominação de raça à de seu sexo, vinculando, portanto, gênero e etnia. O texto evidencia que a ausência de liberdade do negro emana do mesmo sistema que subordina a mulher... $E$ isso muito antes de Simone de Beauvoir promover a equiparação dessas categorias. A mulher é o outro, tanto quanto o negro. Nesse sentido, ganha importância a cena em que a jovem úrsula, presa ao território familiar enquanto aguarda o príncipe encantado, inveja a mobilidade adquirida pelo escravo alforriado.

Além disso, a autora constrói, nos personagens Túlio e Tancredo, traços do ideal do homem sensível, capaz de amar e de sofrer por amor. Este último, em tudo se opõe à brutalidade imperante nas relações entre os gêneros, de que é exemplo o próprio pai:

Não sei por quê, mas nunca pude dedicar a meu pai amor filial que rivalizasse com aquele que sentia por minha mãe, e sabeis por quê? que, entre ele e sua esposa, estava colocado o mais despótico poder: meu pai era o tirano de sua mulher; e ela, triste vítima, chorava em silêncio e resignava-se com sublime brandura (p. 60). 
Nessa crítica, marcada pela fala pesarosa do filho, a autora expressa sua desaprovação ao regime patriarcal. Tancredo ressalta com veemência o "gênio rude" do pai, responsáve pela doença e morte da própria esposa, e pela perseguição e infelicidade amorosa do filho. Desse modo, a narrativa de Maria Firmina incorpora os nascentes valores românticos e liberais para contribuir de modo exemplar com o surgimento de um novo homem, que vai propiciar, por sua vez, a existência de uma nova mulher.

Essas questões, que estão na ordem do dia na contemporaneidade, por si só justificam o a presente edição. No momento em que se buscam as articulações entre as 'minorias' com vistas a políticas comuns de combate à exclusão, e em que se clama pela solidariedade antihegemônica, essa narrativa de 145 anos atrás bem demonstra $o$ valor de nossas primeiras escritoras.

Além do romance, a edição reproduz em apêndice o conto "A escrava", publicado por Maria Firmina dos Reis em 1887, no auge da campanha abolicionista. E novamente o leitor se depara com o discurso do outro, emoldurado pelo ponto de vista dos submetidos. O escravo e a mulher tomam a palavra e falam por todos os que não tinham voz na sociedade e na políica brasileira daquele momento.

Há que se ressaltar ainda o primoroso trabalho editorial que valoriza o romance, e a cuidadosa atualização do texto feita pelo organizador Eduardo de Assis Duarte, a partir do cotejo com as primeiras edições. A 'tradução' para o português contemporâneo limitou-se ao plano vocabular, a fim de conservar a pontuação original e o estilo muito próprio da escritora. Outro ponto a destacar é o posfácio - acurado estudo crítico, que vem acrescentar dados novos à análise das obras. Assim, o leitor contemporâneo tem a oportunidade de conhecer melhor essa história oculta que o texto literário vem iluminar, e também acrescentar uma nova escritora ao panteão das letras nacionais.

Constância Lima Duarte Universidade Federal de Minas Gerais 